\section{CORRECTION OF MAMMAL RECORD}

With reference to "Records of mammals in the Lake Athabasca area, Saskatchewan" in the December, 1964 Blue Jay, the animal which I saw hunting mice in the old warehouse at Lorado was the Least Weasel, not the Ermine. I observed the latter species on numerous occasions at all seasons during my four year residence in the Lorado area.

During the early part of 1959 , I observed a wolf moving at a swift trot across the ice on Beaverlodge Lake. This animal stopped frequently, and looked back. When it had reached a distance of about 300 yards from me, it lay down on the ice, head between paws, and faced me in this position for several minutes, before moving off and resuming its trot in the general direction of Eldorado mine. I was informed that several wolves appeared in the area at this time, apparently attracted by the offal from a chicken farm then in operation at the site of a dis-used mine.-Thomas Heaslip, Co. Down, N. Ireland.

\section{HORNED TOAD RECORD}

by J. David Chandler, Shaunavon

We found the small Horned Toad shown in the accompanying photograph on September 6, 1964, about seven miles southeast of Val Marie in extreme southwestern Saskatchewan, on a slight rise of shale topped with iron deposits, on the floor of the Frenchman River badlands (NW 26. $2-13$ w 3 ). It was about one and threequarters inches in length and was grey in colour. We were especially interested to note that it was in the process of shedding its skin.

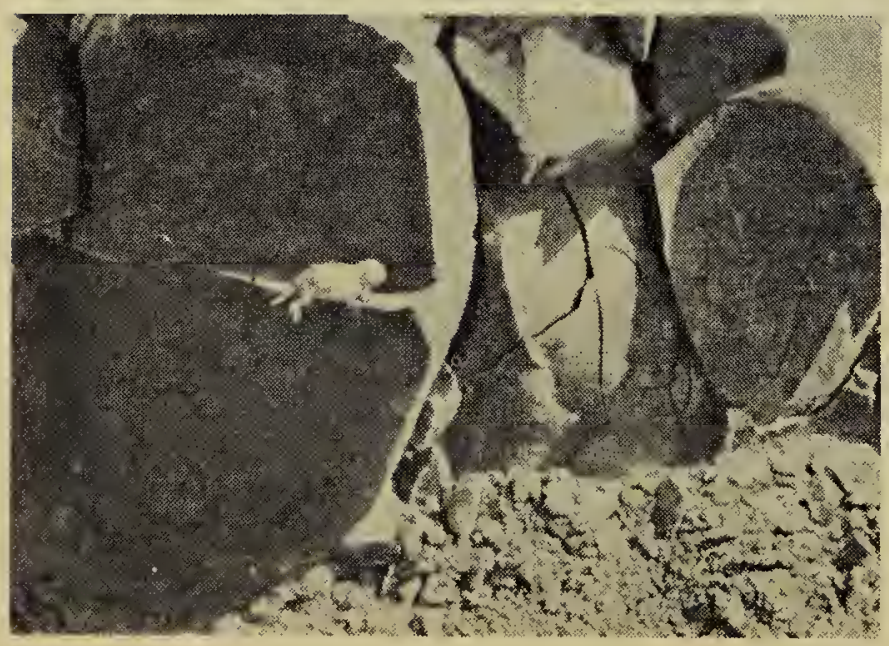

Editor's Note: This reptile, officially known as the Eastern Short-horned Lizard (Phrynosoma douglassi brevirostre), but more commonly called the horned toad, occurs in Canada in extreme southwestern Saskatehewan and southeastern Alberta. Accounts of records in these localities may be found in the September, 1957, Blue Jay (15:119), and in the Canadian Field-Naturalist for October-December, 1963 (Lewin, V. The herpetofauna of southeastern Alberta. 77: 203-214). Lewin lists $: 1$ specimens for Alberta, but there is far less information on the distribution of this lizard in Saskatchewan. The present record appears to be the latest fall observation, which, coupled with the fact that the animal was shedding its skin, is an interesting life history contribution.

\section{THE BOREAL CHORUS FROG IN NORTHERN SASKATCHEWAN}

by W. Harvey Beck, Saskatchewan Museum of Natural History

The Boreal Chorus Frog (Pseudacris triseriata maculata) is a small, long-bodied, short-legged member of the tree frog group. Its general body color is brown or, occasionally, greenish, with three dark stripes running lengthwise down the back and a similar stripe on either side beginning at the nostril and passing back through the eye onto the flank. The stripes may break up into a series of spots. The toes end in very small discs, and the hind toes have small webs. The range of the Boreal Chorus Frog probably extends across Saskatchewan, except for the extreme northeastern corner of the province. The only basis for a known range is actual specimens, and few collections have been made in the northern part of the province. A specimen collected last summer is therefore a noteworthy addition to the known range in Saskatchewan.

On July 7, 1964, a female Boreal Chorus Frog was collected at Stony Rapids on the Fond du Lac River east of Lake Athabasca in a bog surrounded by scrub birch. It was captured by Ronald Hooper while he was in the area collecting insects for the Saskatchewan Museum of Natural 